\title{
PROSPEK USAHA PEMBESARAN LELE SANGKURIANG PROBIOTIK DI DESA SUKOSARI KECAMATAN BELITANG KABUPATEN OKU TIMUR
}

\author{
(Aisah)
}

\begin{abstract}
The purpose of this research were to : (1) To know the cost, income and income obtained by farmers on the cultivation of sangkuriang catfish probiotics in Sukosari Belitang OKU Timur, (2) To know the feasibility of cultivation business of sangkuriang catfish probiotik in Sukosari Belitang OKU Timur. This research was conducted in Sukosari Village, Belitang Sub-District, East OKU Regency. The selection of the location of this study is determined purposively with the consideration that in Sukosari Village there are some farmers who do cultivation of catfish sangkuriang by using probiotics to increase the productivity of catfish. This research was conducted in March 2014. This study found that the total cost of production issued in the cultivation of catfish sangkuriang probiotik in one production cycle is Rp 15.175.709, the total revenue during one production cycle is $R p 20,886,042$ so that Income received amounted to $R p$ 5,710,333. The value of $R / C$ ratio is 1.37 shows the cultivation of probiotic sangkuriang catfish, and the NPV value is $R p$ 21,082,125, the IRR value is $39.79 \%$ and the Net B / C value is 1.79 indicating Cultivation of catfish sangkuriang probiotik feasible (feasible) to be developed.
\end{abstract}

Key Words : Cultivation of Catfish, Probiotics, Marketing Analysis, Income.

\section{PENDAHULUAN}

\section{A. Latar Belakang}

Potensi subsektor perikanan Indonesia sangat besar dikarenakan sektor perikanan merupakan salah satu sumber mata pencaharian bagi sebagian masyarakat Indonesia. Besarnya potensi yang dimiliki subsektor perikanan di Indonesia menyebabkan produksi perikanan Indonesia selalu mengalami peningkatan yang cukup signifikan dari tahun ke tahun. Menurut Kementerian Kelautan dan Perikanan RI, produksi perikanan Indonesia tahun 2010 mencapai 10,83 juta ton atau mengalami kenaikan sebesar 10,29 persen dibandingkan dengan tahun 2009 sebesar 9,82 juta ton. Bahkan pada tahun 2014 pemerintah menargetkan produksi perikanan Indonesia mencapai 22,39 juta ton (DKP 2010).

Ikan lele merupakan salah satu jenis ikan air tawar yang sudah dibudidayakan secara komersial oleh masyarakat Indonesia terutama di Pulau Jawa. Budidaya lele berkembang pesat dikarenakan dapat budidayakan di lahan dan sumber air terbatas dengan padat tebar tinggi, teknologi budidaya yang relatif mudah dikuasai oleh masyarakat, pemasarannya relatif mudah serta modal usaha yang dibutuhkan relatif rendah. Lele juga kaya akan gizi yaitu protein sebesar $20 \%$ dan sangat baik untuk kesehatan karena tergolong makanan dengan kandungan lemak yang relatif rendah dan mineral yang tinggi (Departemen Kelautan dan Perikanan, 2003).
Perikanan modern pada dasarnya merupakan suatu pembangunan perikanan yang berorientasi agribisnis. Sasaran akhir dari pembangunan perikanan keseluruhan adalah meningkatkan pendapatan sekaligus kesejahteraan bagi para petani ikan. Untuk mencapai sasaran tersebut, diperlukan langkah-langkah atau strategi pembangunan perikanan yang mengutamakan keterpaduan baik dalam lingkup lintas sektor, antar sektor maupun wilayah. Dengan pendekatan tersebut, diharapkan dapat terwujud suatu pembangunan perikanan yang mantap dan efisien didalam menunjang pembangunan yang berkelanjutan (Parwinia, 2001).

Usaha budidaya ikan lele merupakan usaha budidaya yang cukup berkembang di Kabupaten OKU Timur, hal ini terlihat bahwa produksi ikan lele di Kabupaten OKU timur mengalami peningkatan yang sangat pesat sebesar $813 \%$ dari 483,8 ton pada tahun 2011 menjadi 4.417,60 ton pada tahun 2012. Berikut adalah produksi ikan lele di Kabupaten OKU Timur :

Tabel 1. Produksi Ikan Lele Kabupaten OKU Timur.

\begin{tabular}{lll} 
No. & Tahun & Produksi (Ton) \\
\hline 1. & 2009 & 186 \\
2. & 2010 & 217,9 \\
3. & 2011 & 483,8 \\
4. & 2012 & $4.417,6$ \\
\hline
\end{tabular}

Sumber: Sumatera Selatan Dalam Angka (Diolah). 
Saat ini keuntungan usaha budidaya ikan lele sangat bergantung kepada kemampuan pembudidaya mengatur hal-hal berikut: benih yang bagus dan murah, nilai konversi pakan yang menjadi daging $(\mathrm{FCR}=$ Feed Conversion Rasio) yang rendah sama dengan 1, ukuran panen seragam 6-10 ekor per $\mathrm{kg}$ dan waktu budidaya pendek. Kestabilan nilai tukar rupiah juga sangat berpengaruh pada naik turunnya harga input produksi ikan lele karena sebagian besar bahan baku utama pakan, yakni; jagung, kedelai, dan tepung ikan masih merupakan bahan impor yang jelas biayanya lebih tinggi. Sedangkan biaya pakan merupakan komponen terbesar dalam usaha budidaya ikan lele. Untuk meningkatkan produksi, biasanya pembudidaya melakukan budidaya ikan lele ke dalam lahan yang terbatas dengan padat tebar tinggi, sehingga diharapkan produksi ikan lele yang dihasilkan akan banyak dan memenuhi permintaan konsumen (Suyanto, 2011).

Pemeliharaan ikan lele dengan padat tebar tinggi dan manajemen pakan yang kurang baik akan membuat kondisi air di kolam akan buruk, karena terjadi penumpukan bahan-bahan organik yang bersifat toksik bagi ikan lele. Dampak dari toksik akan menimbulkan gejala stress, menurunnya nafsu makan, timbulnya berbagai penyakit dan pada akhirnya akan menimbulkan kematian ikan lele, oleh karena itu perlu adanya pengelolaan kualitas air (Nasrudin, 2010).

Penggunaan bahan obat-obatan, antibiotik atau bahan kimia lain yang banyak diaplikasikan dalam produksi perikanan untuk mengantisipasi serangan penyakit, mulai dikurangi mengingat bahan-bahan tersebut dapat mengakibatkan residu pada ikan. Upaya pencegahan penyakit dan usaha untuk meningkatkan kelangsungan hidup hewan budidaya tersebut, saat ini mulai digunakan probiotik dalam usaha pembenihan ikan, Crustacea dan kerang-kerangan. Probiotik itu sendiri adalah makanan tambahan (suplemen) berupa sel-sel mikroorganisme hidup yang memiliki pengaruh menguntungkan bagi hewan inang yang mengkonsumsinya melalui penyeimbangan flora mikro organisme intestinal dalam saluran pencernaan (Irianto, 2007).

Menurut Irianto (2007), pemberian organisme probiotik dalam akuakultur dapat diberikan melalui pakan, air maupun melalui perantaraan pakan hidup seperti rotifera atau artemia. Pemberian probiotik dalam pakan, berpengaruh terhadap kecepatan fermentasi pakan dalam saluran pencernaan, sehingga akan sangat membantu proses penyerapan makanan dalam pencernaan ikan. Fermentasi pakan mampu mengurai senyawa kompleks menjadi sederhana sehingga siap digunakan ikan, dan sejumlah mikroorganisme mampu mensintesa vitamin dan asam-asam amino yang dibutuhkan oleh larva hewan akuatik. Pemberian probiotik pada pelet dengan cara disemprotkan dapat menimbulkan terjadinya fermentasi pada pelet dan meningkatkan kecepatan pencernaan. Selanjutnya akan meningkatkan konversi pakan ikan, peternak dapat memproduksi lele ukuran layak jual dalam waktu lebih singkat (60-70 hari), sehingga dapat menekan biaya produksi.

Penggunaan teknologi mikrobiotik yang lebih dikenal dengan istilah probiotik, mulai banyak digunakan oleh para pembudidaya ikan lele sebagai salah satu cara untuk meningkatkan tingkat kelulusan hidup pada ikan lele dan meningkatkan nafsu makan sesuai dengan kenaikan berat badan dan hasil akhir yang dapat menekan jumlah penggunaan pakan. Hal ini dapat terlihat dari nilai FCR (food convertion ratio) yaitu rasio konversi pakan. Nilai FCR yang lebih kecil mengindikasikan bahwa dibutuhkan pakan yang lebih sedikit untuk mencapai satu kilogram ikan lele.

Teknologi probiotik pada budidaya ikan lele saat ini sedang dikembangkan oleh petani ikan yang tergabung dan dinaungi Sinar Baru Fish Farm yang terletak di Desa Sukosari Kecamatan Belitang Kabupaten OKU Timur. Tujuan pengaplikasian mikroorganisme probiotik pada sistem budidaya lele di Sinar Baru Fish Farm, diharapkan dapat meningkatkan produksi.

\section{B. Rumusan Masalah}

1. Berapa besar biaya, penerimaan dan pendapatan yang diperoleh petani pada budidaya lele sangkuriang probiotik di Sukosari Belitang OKU Timur.

2. Bagaimana kelayakan usaha budidaya lele sangkuriang probiotik di Sukosari Belitang OKU Timur.

\section{Tujuan dan Kegunaan}

1. Untuk menetahui besarnya biaya, penerimaan dan pendapatan yang diperoleh petani pada budidaya lele sangkuriang probiotik di Sukosari Belitang OKU Timur.

2. Untuk mengetahui kelayakan usaha budidaya lele sangkuriang probiotik di Sukosari Belitang OKU Timur. 


\section{Model Pendekatan}

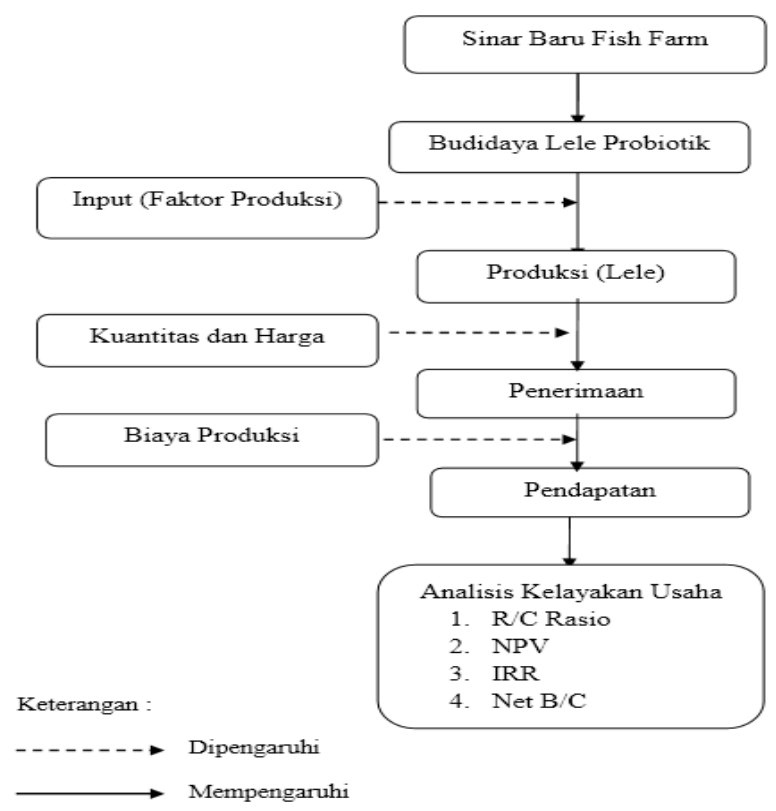

Gambar 1. Model pendekatan penelitian secara diagramatik.

\section{METODOLOGI PENELITIAN}

\section{A. Tempat dan Waktu}

Penelitian ini telah dilaksanakan di Desa Sukosari Kecamatan Belitang Kabupaten OKU Timur. Pemilihan lokasi penelitian ini ditentukan secara sengaja (purposive) dengan pertimbangan bahwa di Desa sukosari terdapat sebagian petani yang melakukan usaha budidaya lele sangkuriang dengan menggunakan probiotik untuk peningkatan produktifitas ikan lele. Penelitian ini telah dilaksanakan pada bulan Maret 2014.

\section{B. Metode Penelitian}

Metode yang akan dilakukan dalam penelitian ini adalah metode Studi Kasus (Case Study) yang bertujuan memperoleh gambaran yang lebih mendalam dari suatu objek yang diteliti. Menurut Nazir (2003), studi kasus adalah penelitian tentang kasus subyek penelitian yang berkenaan dengan suatu fase spesifik atau khas dari keseluruhan personalitas. Subjek penelitian dapat berupa individu, kelompok, lembaga maupun masyarakat. Tujuan studi kasus adalah untuk memberikan gambaran secara detail tentang latar belakang, sifat-sifat serta karakter-karakter yang khas dari kasus atau pun status individu yang kemudian dari sifat-sifat tersebut akan dijadikan suatu hal yang bersifat umum. Penelitian dilakukan dengan mengumpulkan data yang hasilnya dianalisis secara statistik untuk mencari variabel pada sistem budidaya ikan lele probiotik.

\section{Metode Penarikan Contoh}

Metode penarikan contoh yang akan digunakan dalam penelitian ini adalah metode sensus terhadap 12 petani lele probiotik dari 12 populasi. Berdasarkan data dari Sinar Baru Fish Farm terdapat 12 orang petani yang melaksanakan pembesaran lele sangkuriang probiotik di Desa Sukosari. Metode sensus dicirikan dengan mengambil semua populasi sebagai responden (sampel).

\section{Metode Pengolahan Data}

Data yang diperoleh dari penelitian akan dikelompokkan dan kemudian diolah menggunakan teknik komputerisasi dengan bantuan microsoft excel yang akan ditampilkan dalam bentuk tabulasi sehingga dapat dijelaskan secara deskriptif.

a.Untuk mengetahui biaya produksi (Soekartawi, 2002), dengan rumus:

$$
\mathrm{TC}=\mathrm{FC}+\mathrm{VC}
$$

Dimana :

$\mathrm{TC}=$ Total Cost $/$ Biaya Produksi (Rp/Lg/Siklus)

$\mathrm{FC}=$ Fixed Cost/Biaya Tetap (Rp/Lg/Siklus)

$\mathrm{VC}=$ Variable Cost $(\mathrm{Rp} / \mathrm{Lg} / \mathrm{Siklus})$

b. Untuk mengetahui penerimaan, digunakan rumus :

$$
\mathrm{TR}=\mathrm{Q} \times \mathrm{P}
$$

Dimana :

TR = Total Revenue/Penerimaan (Rp/Lg/Siklus)

$\mathrm{Q}=$ Quantity/Hasil Produksi (Kg/Lg/Siklus)

$\mathrm{P}=$ Price/Harga Jual $(\mathrm{Rp} / \mathrm{Kg})$

c. Untuk menghitung pendapatan, digunakan rumus :

$$
\pi=\mathrm{TR}-\mathrm{TC}
$$

Dimana :

$\pi=$ Income $/$ Pendapatan $(\mathrm{Rp} / \mathrm{Lg} /$ Siklus $)$

$\mathrm{TR}=$ Total Revenue/Penerimaan $(\mathrm{Rp} / \mathrm{Lg} /$ Siklus $)$

$\mathrm{TC}=$ Total Cost /Total Biaya Produksi (Rp/Lg/Siklus)

d. $\mathrm{R} / \mathrm{C}$ ratio dihitung dengan menggunakan rumus ;

$$
\mathrm{R} / \mathrm{C} \text { ratio }=\frac{\mathrm{TR}}{\mathrm{TC}}
$$

Dimana :

$\mathrm{R} / \mathrm{C}=$ Return Cost rasio $(\mathrm{Rp})$

$\mathrm{TR}=$ Total Revenues $/$ Penerimaan $(\mathrm{Rp} / \mathrm{Lg} /$ Siklus $)$

$\mathrm{TC}=$ Total Cost/Biaya Total $(\mathrm{Rp} / \mathrm{Lg} /$ Siklus $)$

Dengan kriteria :

R/C Ratio > 1 Berarti usahatani menguntungkan 
R/C Ratio = 1 Berarti usahatani tidak untung dan tidak rugi (impas)

$\mathrm{R} / \mathrm{C}$ Ratio < 1 Berarti usahatani tidak menguntungkan (rugi)

e.Untuk menghitung NPV maka digunakan rumus :

$$
N P V=\Sigma \quad \frac{B t-C t}{(1+i)^{n}}-K o
$$

Dimana :

$\mathrm{NPV}=$ Net Present Value

Ko $=$ Kapital yang digunakan pada periode investasi.

$\mathrm{Bt}=$ Penerimaan pada tahun ke-t.

$\mathrm{Ct}=$ Pengeluaran discount faktor (bunga bank).

Dengan kriteria :

NPV > 0 maka usaha layak (feasible)

NPV < 0 maka usaha tidak layak untuk dilaksanakan

$\mathrm{NPV}=0$ maka usaha dalam keadaan impas

f.Untuk menghitung Internal Rate Ratio (IRR) maka digunakan rumus :

$$
I R R=i_{1}+\frac{N P V_{1}}{\left(N P V_{1}-N P V_{2}\right)} \times\left(i_{2}-i_{1}\right)
$$

Dimana :

$$
\begin{array}{ll}
\mathrm{NPV}_{1}= & \mathrm{NPV} \text { pada tingkat discount rate } \\
& \text { tertinggi (positif). } \\
\mathrm{NPV}_{2}= & \mathrm{NPV} \text { pada tingkat discount rate } \\
& \text { terendah (negatif). } \\
\mathrm{i}_{1} & =\text { Discount rate terendah } \\
\mathrm{i}_{2} & =\text { Discount rate tertinggi }
\end{array}
$$

Dengan kriteria :

IRR > SOCC (bunga bank) maka usaha layak (feasibel).

IRR < SOCC maka usaha tidak layak.

g. Untuk menghitung nilai net $\mathrm{B} / \mathrm{C}$ ratio maka digunakan rumus :

$$
\text { Net B/C }=\frac{\sum \mathrm{NB}(+)}{\sum \mathrm{NB}(-)}
$$

Dimana :

$\Sigma$ NB (+) $=$ Net Benefit yang telah didiscount positif

$\Sigma$ NB (-) $=$ Net Benefit yang telah didiscount negatif

Dengan kriteria :

Net B/C > 1 Berarti usahatani menguntungkan/ layak dikembangkan.

Net $\mathrm{B} / \mathrm{C}=1$ Berarti usahatani tidak untung dan tidak rugi (impas).

Net $B / C<1$ Berarti usahatani tidak menguntungkan (rugi).

\section{HASIL DAN PEMBAHASAN}

\section{A. Analisa Biaya, Penerimaan, dan Pendapatan Pembesaran Lele Sangkuriang Probiotik.}

Biaya merupakan suatu hal penting yang harus diperhatikan dalam usaha pembesaran lele sangkuriang, karena biaya dapat menunjukkan kondisi usaha yang dijalankan. Biaya adalah pengorbanan sumber ekonomi yang diukur dalam satuan uang yang telah terjadi atau kemungkinan akan terjadi untuk mencapai tujuan tertentu (Mulyadi, 2007). Biaya yang terdapat pada pembesaran lele sangkuriang probiotik dan non probiotik terdiri dari dua komponen, yaitu biaya tetap dan biaya variabel.

Menurut Hanafie (2010), biaya tetap adalah semua jenis biaya yang besar kecilnya tidak tergantung pada besar kecilnya produksi. Yang termasuk dalam kelompok biaya tetap, misalnya sewa tanah yang berupa uang atau pajak yang penentuannya berdasarkan luas lahan. Jumlah biaya tetap adalah konstan. Sedangkan biaya variabel adalah biaya yang besar kecilnya berhubungan langsung dengan besar kecilnya produksi seperti biaya bibit/benih, pupuk, dan tenaga kerja.

\section{a. Biaya Produksi}

Dalam hasil penelitian pembesaran lele sangkuriang probiotik dan non probiotik di Desa Sukosari Kecamatan Belitang Kabupaten OKU Timur biaya produksi yang dikeluarkan terdiri dari biaya tetap dan biaya variabel. Kegiatan pembesaran lele sangkuriang probiotik dan non probiotik di desa Sukosari Kecamatan Belitang Kabupaten OKU Timur, dalam penggunaan lahannya memiliki status kepemilikan lahan sendiri.

Akan tetapi kaidah dalam usahatani semuanya dianggap sebagai lahan sewa. Karena untuk petani dengan status kepemilikan lahan sendiri juga melakukan pembayaran pajak lahan. Berikut adalah rincian biaya produksi pada pembesaran lele sangkuriang probiotik di Desa Sukosari Kecamatan Belitang, Kabupaten OKU Timur : 
Tabel 2. Rata-rata Total Biaya Pembesaran Lele Probiotik di Desa Sukosari.

\begin{tabular}{lrr}
\hline \multirow{2}{*}{ No. Komponen Biaya } & \multicolumn{2}{c}{ Jumlah } \\
& (Rp/LG/Siklus) & \multicolumn{2}{c}{$\left(\mathrm{Rp} / 100 \mathrm{~m}^{2} /\right.$ Siklus $)$} \\
\hline 1. Biaya Tetap & $\mathbf{2 4 1 . 7 0 3}$ & $\mathbf{2 5 3 . 9 0 1}$ \\
a. Sewa lahan & 120.833 & 125.000 \\
b. Penyusutan alat & 120.870 & 128.901 \\
2. Biaya Variabel & $\mathbf{1 4 . 9 3 4 . 0 0 6}$ & $\mathbf{1 5 . 5 2 5 . 4 8 7}$ \\
a. Tenaga kerja & 1.543 .333 & 1.644 .603 \\
b. Biaya saprodi & 13.390 .673 & 13.880 .883 \\
3. Total Biaya Produksi & $\mathbf{1 5 . 1 7 5 . 7 0 9}$ & $\mathbf{1 5 . 7 7 9 . 3 8 7}$ \\
\hline
\end{tabular}

Sumber : Data Primer, 2014.

Pada tabel di atas, dapat dilihat bahwa ratarata biaya tetap yang dikeluarkan oleh petani lele probiotik dalam satu kali siklus yang terdiri atas biaya sewa lahan dan biaya penyusutan peralatan adalah sebesar Rp. 241.703,- per luas garapan $\left(96,67 \mathrm{~m}^{2}\right)$, dan sebesar Rp. 253.901,- per $100 \mathrm{~m}^{2}$. Besarnya biaya variabel yang terdiri atas biaya tenaga kerja dan biaya saprodi adalah sebesar Rp 14.934.006, per luas garapan dan sebesar Rp. 15.525.487,- per $100 \mathrm{~m}^{2}$ sehingga rata-rata total biaya produksi yang dikeluarkan dalam satu kali siklus produksi adalah sebesar Rp. 15.175.709,per luas garapan $\left(90,53 \mathrm{~m}^{2}\right)$, dan sebesar Rp. 15.779.387,- per $100 \mathrm{~m}^{2}$.

\section{b. Penerimaan dan Pendapatan}

Penerimaan masing-masing petani yang dihitung selama penelitian hanya penerimaan dari hasil penjualan lele sangkuriang hasil pembesaran. Masing-masing petani melakukan penjualan lele sangkuriang hasil pembesaran secara langsung ke tengkulak ikan di Desa Sukosari Kecamatan Belitang Kabupaten OKU Timur. Penerimaan usaha pembesaran lele sangkuriang probiotik di Desa Sukosari Kecamatan Belitang Kabupaten OKU Timur dapat dilihat pada tabel berikut;

Tabel 3. Rata-rata Penerimaan Pembesaran Lele Probiotik di Desa Sukosari.

\begin{tabular}{llrr}
\hline No. & \multicolumn{1}{c}{ Uraian } & \multicolumn{2}{c}{$\begin{array}{c}\text { Jumlah } \\
\text { (Rp/LG/Siklus) }\end{array}$} \\
\hline 1. & Penerimaan I & 19.098 .083 & 19.711 .972 \\
& a. Produksi $(\mathrm{Kg})$ & 1.123 & 1.160 \\
& b. Harga & 17.000 & 17.000 \\
2. Penerimaan II & 1.787 .958 & 1.877 .826 \\
& a. Produksi (Kg) & 103 & 108 \\
& b. Harga & 17.333 & 17.333 \\
3. Total Penerimaan & 20.886 .042 & 21.589 .799
\end{tabular}

Sumber : Data Primer, 2014.
Berdasarkan tabel diatas terlihat bahwa penerimaan total selama satu periode pembesaran pada lele probiotik adalah sebesar $\mathrm{Rp}$ 20.886.042/Lg $\left(97 \quad \mathrm{M}^{2}\right)$ atau sebesar $\mathrm{Rp}$ 21.589.799,- per $100 \mathrm{~m}^{2}$. Pemanenan lele sangkuriang di Desa Sukosari dalam satu siklus dilakukan dua kali pemanenan. Produksi I (pemanenan pertama saat umur \pm 50 hari) merupakan hasil panen yang telah masuk kriteria ukuran konsumsi (5-6 ekor $/ \mathrm{kg})$. Sedangkan produksi II merupakan produksi lele sangkuriang dari hasil panen pertama yang belum masuk kriteria.

Pendapatan pada pembesaran lele sangkuriang di Desa Sukosari merupakan selisih penerimaan dengan biaya yang telah dikeluarkan. Pendapatan juga disebut keuntungan atau laba dari suatu usaha, pendapatan yang diterima pada pembesaran lele sangkuriang probiotik di Desa Sukosari adalah sebagai berikut :

Tabel 4. Rata-rata Pendapatan Lele Sangkuriang Probiotik di Desa Sukosari Kecamatan Belitang Kabupaten OKU Timur.

\begin{tabular}{llrr}
\hline \multirow{2}{*}{ No. } & \multicolumn{1}{c}{ Uraian } & \multicolumn{2}{c}{ Jumlah } \\
\cline { 3 - 4 } 1. & Total Penerimaan & 20.886 .042 & \multicolumn{1}{c}{ (Rp $100 \mathrm{~m}^{2} /$ Siklus $)$} \\
2. & Total Biaya & 15.175 .709 & 15.589 .799 \\
3. & Pendapatatan & 5.779 .387 & \\
4. & RC Rasio & 1,373 & 5.810 .411 \\
\end{tabular}

Sumber : Data Primer, 2014.

Berdasarkan tabel di atas, total rata-rata penerimaan usaha pembesaran lele probiotik dalam satu periode pembesaran adalah $\mathrm{Rp}$. 21.589.799,- per $100 \mathrm{~m}^{2}$. Biaya total produksi yang dikeluarkan sebesar Rp 15.779 .387 per 100 $\mathrm{m}^{2}$. maka pendapatan yang diperoleh dalam usaha budidaya lele probiotik dalam satu periode pembesaran adalah sebesar Rp 5.710.333 per luas garapan $\left(97 \mathrm{M}^{2}\right)$ atau sebesar Rp 5.810.411 per $100 \mathrm{~m}^{2}$. Perhitungan R/C dilakukan melalui pembagian total penerimaan dengan total biaya produksi. Nilai R/C rasio pembesaran lele sangkuriang probiotik per satu periode pembesaran adalah 1,37 yang berarti bahwa setiap satu rupiah yang biaya yang dikeluarkan untuk kegiatan usaha pembesaran lele sangkuriang probiotik maka akan memberikan penerimaan sebesar $\mathrm{Rp}$ 1,31. Nilai $\mathrm{R} / \mathrm{C}$ ini menunjukan bahwa usaha pembesaran lele sangkuriang probiotik di Desa Sukosari menguntungkan. 


\section{B. Analisa Kelayakan Usaha Budidaya Ikan Lele Sangkuriang Probiotik.}

\section{Analisa NPV}

Net Present Value (NPV) atau nilai sekarang bersih adalah analisis manfaat finansial yang digunakan untuk mengukur layak tidaknya suatu usaha dilaksanakan dilihat dari nilai sekarang (present value). Keuntungan dari suatu proyek adalah besarnya penerimaan dikurangi pembiayaan yang dikeluarkan. Dapat dikatakan bahwa NPV adalah selisih antara Present Value dari arus Benefit dikurangi Present Value PV dari arus biaya (Soekartawi, 1996).

Kriteria kelayakan dari proyek ini adalah: Proyek layak jika NPV bertanda positif dan sebaliknya tidak layak jika NPV bertanda negatif. Tabel 5. Analisa NPV Usaha Budidaya Ikan Lele Sangkuriang Probiotik di Desa Sukosari Belitang OKU Timur, 2014.

\begin{tabular}{|c|c|c|c|c|c|}
\hline \multirow[b]{2}{*}{ No } & \multicolumn{5}{|c|}{ TAHON } \\
\hline & Uraian & to & tl & 02 & B \\
\hline 1 & Peneriman & & 83.54 .167 & 86.050 .492 & 88.632 .006 \\
\hline 2 & Biaya-biaya & & & & \\
\hline & a. Investasi Awal & 26.735 .208 & & & \\
\hline & b. Total Biaja Produksi & & 60.702 .835 & 63.737 .976 & 68.199 .635 \\
\hline 3 & Pendapatan & -26.735 .208 & $22.841 .331,93$ & $22.312,515,19$ & 20.432 .372 \\
\hline 4 & dfat $18 \%$ & 1,00 & 0,85 & 0,72 & 0,61 \\
\hline 5 & NPV at $18 \%$ & 26.735 .208 & 19.357 .061 & 16.024 .501 & 12.435 .772 \\
\hline & TotalNPV & $21,082,125,77$ & & & \\
\hline
\end{tabular}

Sumber : Olahan Data Primer, 2014.

Hasil analisis pada Tabel diatas diperoleh nilai investasi awal untuk pembelian lahan dan alat-alat produksi adalah sebesar Rp 26.735.208 sehingga pendapatan pada tahun ke 0 adalah $\mathrm{Rp}$ 26.735.208. Dari perhitungan NPV selama tiga tahun dengan tingkat bunga $18 \%$ maka diperoleh nilai NPV adalah sebesar Rp 21.082.125,77 dan nilai NPV >0, hal ini menunjukan bahwa usaha budidaya lele sangkuriang probiotik ini menguntungkan dan layak untuk dikembangkan.

\section{Analisa IRR (Internal Rate of Return)}

IRR menunjukkan kemampuan suatu investasi atau usaha dalam menghasilkan return atau tingkat keuntungan yang bisa dipakai. Kriteria yang dipakai untuk menunjukkan bahwa suatu usaha layak dijalankan adalah jika nilai IRR lebih besar dari tingkat suku bunga yang berlaku pada saat usahatani tersebut diusahakan (Gittinger, 1993). Jadi, jika IRR lebih tinggi dari tingkat bunga bank, maka usaha yang direncanakan atau yang diusulkan layak untuk dilaksanakan.
Tabel 6. Analisa Perhitungan IRR Usaha Budidaya Lele Sangkuriang Probiotik di Desa Sukosari Belitang Timur OKU Timur, 2014.

\begin{tabular}{|c|c|c|c|c|c|c|}
\hline Tahun & Net Benefit & ffat $18 \%$ & NPV at $18 \%$ & & & NPV at 40\% \\
\hline 0 & -26.735 .208 & & -26.735 .2 & & 1,00 & -26.735 .208 \\
\hline 1 & 22.841.332 & & 19.357. & & 0,71 & 13.826.472 \\
\hline 2 & 22.312.515 & & 16.024. & & 0,51 & 8.175 .766 \\
\hline 3 & 20.432 .372 & & 12.435. & & 0,36 & 4.531.987 \\
\hline \multicolumn{6}{|c|}{21.082 .126} & -200.983 \\
\hline NPVt & NPV. & (PYH).APV.) & 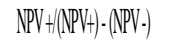 & (ii) & 18 & $(12-1-1)$ \\
\hline 21.082 .126 & (200.983) & 21.283 .109 & 0,900557 & 0,18 & 0,4 & $0,2 \quad 39,79$ \\
\hline
\end{tabular}

Sumber : Olahan Data Primer, 2014.

$\operatorname{IRR}=$

$$
i_{1}+\frac{N P V+}{(N P V+)-(N P V-)} \quad\left(i_{2}-i_{1}\right)
$$

$\mathrm{IRR}=$

$$
0,18+\frac{21.082 .126}{21.283 .109} \times 0,4-0,18
$$

$=$

$$
0,18+0,990557 \times 0,22
$$

$=$

39,792247

Berdasarkan hasil perhitungan, diperoleh nilai IRR adalah sebesar 39,79 yang berarti nilai IRR > nilai suku bunga bank (SOCC) sebesar 18\%. Hal ini menunjukan bahwa usaha budidaya ikan lele probiotik di Desa Sukosari menguntungkan dan layak (feasible) untuk dikembangkan.

\section{Analisa Net B/C}

Benefit Cost Ratio adalah penilaian yang dilakukan untuk melihat tingkat efisiensi penggunaan biaya berupa perbandingan jumlah nilai bersih sekarang yang positif dengan jumlah nilai bersih sekarang yang negatif, atau dengan kata lain $\mathrm{Net} \mathrm{B} / \mathrm{C}$ adalah perbandingan antara jumlah NPV positif dangan jumlah NPV negatif dan ini menunjukkan gambaran berapa kali lipat benefit akan kita peroleh dari cost yang kita keluarkan. Kriteria ini memberikan pedoman bahwa suatu proyek akan dipilih apabila nilai ( $\mathrm{Net}$ $B / C>1)$, sebaliknya bila suatu proyek memberikan nilai (Net $B / C<1)$, maka proyek tidak akan diterima (diteruskan). 


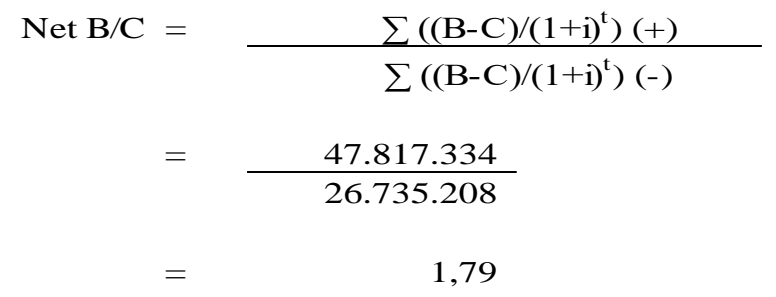

Hasil perhitungan, diperoleh nilai Net $\mathrm{B} / \mathrm{C}$ sebesar 1,79 , nilai Net $\mathrm{B} / \mathrm{C}>1$ berarti usaha budidaya ikan lele sangkuriang probiotik menguntungkan dan layak dikembangkan. Nilai Net B/C tersebut memiliki arti bahwa setiap Rp. 1 yang dikorbankan untuk budidaya ikan lele sangkuriang maka akan meraih keuntungan sebesar Rp 1,79. Berdasarkan perhitungan analisa NPV, IRR dan Net B/C menunjukan bahwa usaha budidaya ikan lele sangkuriang probiotik di Desa Sukosari Kecamatan Belitang Kabupaten OKU Timur menguntungkan dan layak (feasibel) untuk dikembangkan.

\section{IV.KESIMPULAN DAN SARAN}

\section{A. Kesimpulan}

Berdasarnya hasil penelitian dan analisis yang telah dilakukan, maka dapat ditarik kesimpulan sebagai berikut:

1. Biaya total produksi yang dikeluarkan dalam budidaya ikan lele sangkuriang probiotik dalam satu kali siklus produksi adalah sebesar Rp 15.175.709, total penerimaan selama satu kali siklus produksi adalah sebesar Rp 20.886.042 sehingga pendapatan yang diterima adalah sebesar $\mathrm{Rp}$ 5.710.333. Nilai $\mathrm{R} / \mathrm{C}$ rasio adalah sebesar 1,37 menunjukan usaha budidaya ikan lele sangkuriang probiotik menguntungkan.

2. Nilai NPV adalah sebesar Rp 21.082.125, nilai IRR adalah sebesar 39,79\% dan nilai Net B/C adalah sebesar 1,79 yang menunjukkan usaha budidaya ikan lele sangkuriang probiotik layak (feasible) untuk dikembangkan.

\section{B. Saran}

Adapun saran yang dapat disampaikan oleh penulis adalah : Petani lele sangkuriang probiotik diharapkan dapat meningkatkan keterampilan dan kemampuannya dalam budidaya lele probiotik yaitu dengan mengikuti pelatihan mengenai budidaya ikan lele sangkuriang probiotik secara intensif. Sehingga dapat meningkatkan produksi melalui peningkatan padat tebar ikan menjadi 150-200 ekor per $\mathrm{m}^{3}$.

\section{DAFTAR PUSTAKA}

Arikunto dan Suharsimi. 2002. Prosedur Penelitian Suatu Pendekatan Praktek. Jakarta: Rineka Cipta.

Anonim. 2003. Mikroba Probiotik : Penunjang Agribisnis dan Penyelamatan Lingkungan. Dalam PPAU Ilmu Hayati ITB. http://tl.lib.itb.ac.id/go.php?id=jbpksimbagdl-grey-2003-ppauilmuha-4

Irianto, A. 2007. Potensi Mikroorganisma : Di Atas Langit Ada Langit. Ringkasan Orasi Ilmiah di Fakultas Biologi Universitas Jenderal Sudirman Tanggal 12 Mei.

Mahyuddin, K., 2008. Panduan Lengkap Agrobisnis Lele. Jakarta: Penebar Swadaya

Departemen Kelautan dan Perikanan. 2007. Budidaya Lele Sangkuriang. http ://www.dkp.go.id/content.php?c=2558.

Khairuman dan Khairul A. 2002. Budi Daya Lele Dumbo Secara Intensif. PT. Agromedia Pustaka. Jakarta.

Parwinia. 2001. Evaluasi Kebijakan Perikanan Mengenai "Pengembangan Agribisnis Terpadu" .Makalah Falsafah Sains (PPs 702) Program Pasca Sarjana /S3 IPB diakses tanggal 3 November 2007.

Rachmatun, S. 1997. Budidaya Ikan Lele. Penebar Swadaya. Jakarta.

. 2002. Budidaya Ikan Lele. Penebar Swadaya. Jakarta.

Soetomo, M. 2000. Teknik Budidaya Ikan Lele Dumbo. Sinar Baru Algasindo. Bandung.

Suyanto, S.R. 2007. Budidaya Ikan Lele. Penebar Swadaya. Jakarta.

Khairuman dan Khairul, A. 2002. Budidayan Lele Dumbo Secara Intensif dan Pemasarannya. Jakarta Agromedia Pustaka.

Khairuman dan Khairul, A. 2009. Buku Pintar Budidaya 15 Ikan Konsumsi. Agromedia. Jakarta.

Kotler, P. 2001. Dasar-Dasar Pemasaran. Edisi ke- 3. Penerbit Intermedia, Jakarta.

Limbong, W.H dan Sitorus, P. 2003. Pengantar Tataniaga Pertanian jurusan Ilmu-Ilmu Sosial Pertanian. Fakultas Pertanian. IPB.Bogor.

Manulang, 2005. Harga Dalam Proses Produksi. Grafindo. Jakarta.

Mubyarto. 2003. Pengantar Ilmu Pertanian. Lembaga Penelitian,Pendidikan Dan Penerangan Ekonomi. Jakarta.

Najiyati, S. 2007. Memelihara Lele Dumbo di Kolam Terpal. Penerbit Swadaya. Jakarta. 
Saefudin, AM. 2002. Pemasaran Produk Pertanian. Institut Pertanian Bogor.

Saragih. B. 2007. Agribisnis Berbasis Pertanian. Pusat Studi Pengembangan Lembaga Penenelitian Insitut Pertanian Bogor. Bogor. Simanjutak, R.H. 2000. Pembudidayaan Ikan Lele Lokal dan Dumbo. Bhratara. Jakarta.

Sjarkowi, F. dan Sufri, M. 2004. Manajemen Agribisnis. CV Baldad Grafiti Press. ISBN 979-96207-1-6. Palembang.
Soeharjo Dan Patong. 2003. Sendi-Sendi Pokok Ekonomi Usahatani. Departemen Ilmu-Ilmu Sosial Ekonomi Pertanian Fakultas Pertanian Bogor. Bogor.

Soekartawi. 2005. Prinsip Dasar Ekonomi Pertanian. Raja Grafindo Persada.

Sudiyono dan Armand. 2007. Manajemen Pemasaran Pertanian. UMM-Press. Malang. 